\title{
Manglende modning av venstre ventrikkels myokard
}

\author{
Sammendrag \\ Bakgrunn. Manglende modning Inon- \\ compaction) av venstre ventrikkels \\ myokard er ganske nylig beskrevet \\ som en årsak til dysfunksjon av venstre \\ ventrikkel. I det følgende vil vi beskrive \\ epidemiologiske og kliniske aspekter \\ ved denne tilstanden, som manifeste- \\ rer seg klinisk $\mathrm{i}$ alle aldre.
}

Metode. Artikkelen er basert på en gjennomgang av artikler fra eget litteraturarkiv samt relevante referanser fra disse artiklene.

Resultater. Tilstanden skyldes ufullstendig endomyokardial embryogenese og vil ofte medføre hjertesvikt, systemiske embolier og/eller ventrikulære arytmier. Diagnosen stilles ved todimensjonal ekkokardiografi eller magnetisk resonanstomografi (MR) av hjertet. Forandringene affiserer venstre ventrikkels myokard, og predileksjonssteder er apex og nedre og laterale veggs midtre og distale segmenter. I de affiserte områdene påvises det et tynnere og normalt modnet ytre myokardlag, mens det indre myokardlaget mot endokard er trabekulært fortykket, med dype intertrabekulære recesser. Tilstanden kan være isolert med eller uten ekstrakardiale tilleggslidelser, eller den kan være assosiert med andre kardiale malformasjoner.

Fortolkning. Det er viktig å ikke overse manglende modning av myokard, siden tilstanden kan ha alvorlige følger i form av hjertesvikt, tromboemboliske hendelser, ventrikulære takyarytmier og død. Tidlig diagnose vil kunne gi disse pasientene en bedre oppfølging og behandling.

\author{
Sahrai Saeed \\ sahrai.saeed@helse-sunnmore.no \\ Johnny Vegsundvåg \\ Medisinsk avdeling \\ Inge Lode \\ Røntgenavdelingen \\ Ålesund sjukehus \\ 6026 Ålesund
}

Manglende modning av venstre ventrikkel er rapportert å forekomme hos mindre enn $1 \%$ av pasientene i forskjellige ekkokardiografiske materialer og kan foreligge som familiær disposisjon. Tilstanden er ganske nylig beskrevet som en årsak til dysfunksjon av venstre ventrikkel (1-6) og skyldes feil i den endomyokardiale embryogenesen (1). Den kan både hos barn og voksne medføre hjertesvikt, systemiske embolier og/eller ventrikulære arytmier (1, 2, 7-9). Diagnosen stilles ved todimensjonal ekkokardiografi eller MR av hjertet $(5,7,9-12)$. Typisk påvises venstre ventrikkels myokard med et tynnere og normalt utviklet ytre lag, mens det indre laget mot endokard er trabekulært fortykket, med dype intertrabekulære recesser (fig 1).

\section{Materiale og metode}

Artikkelen er basert på en gjennomgang av artikler fra eget litteraturarkiv samt relevante referanser hentet fra disse artiklene.

\section{Morfologi og diagnose}

Under embryogenesen består hjertet av et nettverk av muskelfibre som normalt fortettes, og de intertrabekulære sinusoidene degenerer. Denne myokardmodningen (compaction) foregår i 5.-8. svangerskapsuke og medfører at de intertrabekulære sinusoidene omdannes til kapillærer. Prosessen starter fra epikard og fortsetter innover til endokard, fra basis av hjertet til apex, og er mer fullkommen i venstre ventrikkel enn i høyre. Samtidig utvikles den koronare sirkulasjonen $(1,13)$. Ved manglende modning går denne prosessen i stå. Dette resulterer i multiple persisterende og tydelige ventrikulære trabekler og dype intertrabekulære recesser som kommuniserer med ventrikkelkaviteten og ikke med koronarsirkulasjonen (fig 1, fig $2)$. De intertrabekulære recessene og ventrikkelkaviteten er kledd med sammenhengende endotel $(1,2,5)$. Predileksjonssteder for denne manglende modningen, som man ellers finner normalt hos fisker, amfibier og krypdyr (4), er venstre ventrikkels midtre og distale segmenter av laterale og nedre vegg samt apexavsnittet $(5,9,13)$. Graden av endringer varierer fra pasient til pasient $(1,4)$.

I den engelskspråklige litteraturen har det vært brukt en rekke synonymer for tilstanden, som «isolated left ventricle noncompaction», «honeycombed myocardium», «spongy myocardium», «persisting myocardial sinusoids», «myocardial disorganization» og «left ventricle hypertrabeculation» $(4,7)$. I prinsippet representerer alle disse begrepene samme tilstand.

Manglende modning av venstre ventrikkel ble første gang beskrevet i 1932 ved obduksjon av et nyfødt barn med aortaatresi og koronoventrikulær fistel (14). Senere har det kommet flere artikler om tilstanden, inklusive oversiktsartikler $(1-6,15,16)$. Manglende modning av venstre ventrikkel kan være assosiert med andre hjertemisdannelser (som ventrikkelseptumdefekt og utløpshindre for ventriklene), eller tilstanden kan være isolert med eller uten sjeldne ekstrakardiale tilstander (for eksempel systemiske myopatier og facial dysmorfisme) (2-7, 9-11). I det følgende er det den isolerte formen uten ekstrakardiale tilstander som omtales, med mindre annet er presisert.

Etter hvert har man fått økt kunnskap om patogenese, diagnostikk og prognose, og tilstanden er nylig blitt klassifisert som en primær kardiomyopati (17). Ekkokardiografi eller MR-undersøkelse (12) av hjertet angis som gullstandard for diagnostikk. Flere ekkokardiografiske funn angis som typiske $(2,5$, 7,9-11):

- fravær av andre hjertemisdannelser (per definisjon).

- affeksjon av apex og/eller apikale og/eller midtventrikulære segmenter av nedre og/ eller laterale vegg. Mer enn $80 \%$ av pasien-

\section{Hovedbudskap}

- Manglende modning av venstre ventrikkels myokard disponerer for hjertesvikt, systemiske tromboembolier, alvorlige ventrikulære arytmier og $\mathrm{d} ø \mathrm{~d}$

- Årsaken til tilstanden er ufullstendig endomyokardial utvikling av venstre ventrikkel i fosterlivet

- Manglende modning diagnostiseres ved bruk av todimensjonal ekkokardiografi og/eller MR av hjertet

- Det er grunn til å tro at tilstanden forekommer hyppigere enn tidligere antatt 
ter med denne tilstanden har manglende modning på ett eller flere av disse predileksjonsstedene.

- tre eller flere uttalte myokardtrabekler vurdert i samme bildeplan.

- dype intertrabekulære recesser som kommuniserer med ventrikkelkaviteten.

- de affiserte myokardavsnittene er tolaget, bestående av et tynt ytre epikardialt lag og et fortykket trabekulært indre endokardialt lag.

- det ytre myokardlaget er fortettet på normal måte, mens det indre laget ikke er fortettet. Ved måling av tykkelsen av veggsegmentene i endesystolen, vil forholdet mellom det ikke-fortettede og det fortettede laget typisk være $>2,0$.

Det er ikke full enighet internasjonalt om de endelige diagnostiske kriteriene for tilstanden, og ett eller flere av disse ekkokardiogra- fifunnene kan finnes ved andre tilstander eller sykdommer som affiserer venstre ventrikkel. Tilstedeværelse av alle de ovenfornevnte kriteriene angis imidlertid som meget spesifikt for diagnosen (11). Ved usikre funn kan bruk av intravenøst ekkokontrastmiddel være nyttig for å sikre diagnosen (18). Ved MR av hjertet angis funn av en ikke-fortetning/fortetningsratio $\geq 2,3$ ved måling i ventrikkelens endediastole som typisk for tilstanden (12) (fig 3). Andre bildedannende undersøkelsesmetoder av hjertet kan være av verdi, så som computertomografiundersøkelser og ventrikulografi (19).

Høyre ventrikkel er normalt tydelig trabekulert. Ved manglende modning av venstre ventrikkel kan man imidlertid i opptil halvparten av tilfellene også finne tilsvarende forandringer i form av mer uttalt trabekulering i høyre ventrikkel (1).

Patohistologiske funn ved manglende modning av venstre ventrikkel er uspesifikke. Myokardbiopsier er beskrevet som normale eller med subendokardial fibrose/fibroelastose, myokardial fibrose, myokardial hypertrofi og degenerasjon, arrdanning $i$ myokard eller tegn på inflammasjon $(4,7$, 8). Elektronmikroskopi har vist normal myofibrillarkitektur med eller uten lett forstørrede mitokondrier (7).

Det kan foreligge uspesifikke EKG-forandringer, så som venstre ventrikkel-hypertrofi, venstre og høyre grenblokk, hemiblokk og ST-T-forandringer $(1,3,6,8,11)$.

Flere differensialdiagnoser bør has i mente, så som uttalte myokardtrabekler (typisk mindre enn tre) i normal ventrikkel, hypertrofisk kardiomyopati (dype recesser kommuniserer ikke med ventrikkelkaviteten), dilatert og restriktiv kardiomyopati, endokardial fibroelastose, venstre ventrikkeltromber (spesielt apikalt), intraventrikulære bånd, in-

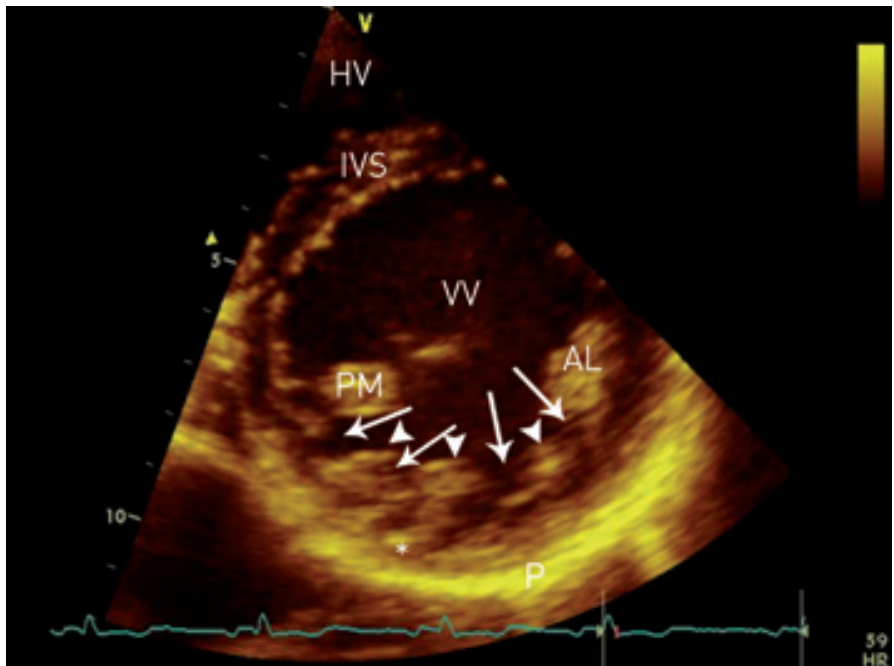

Figur 1

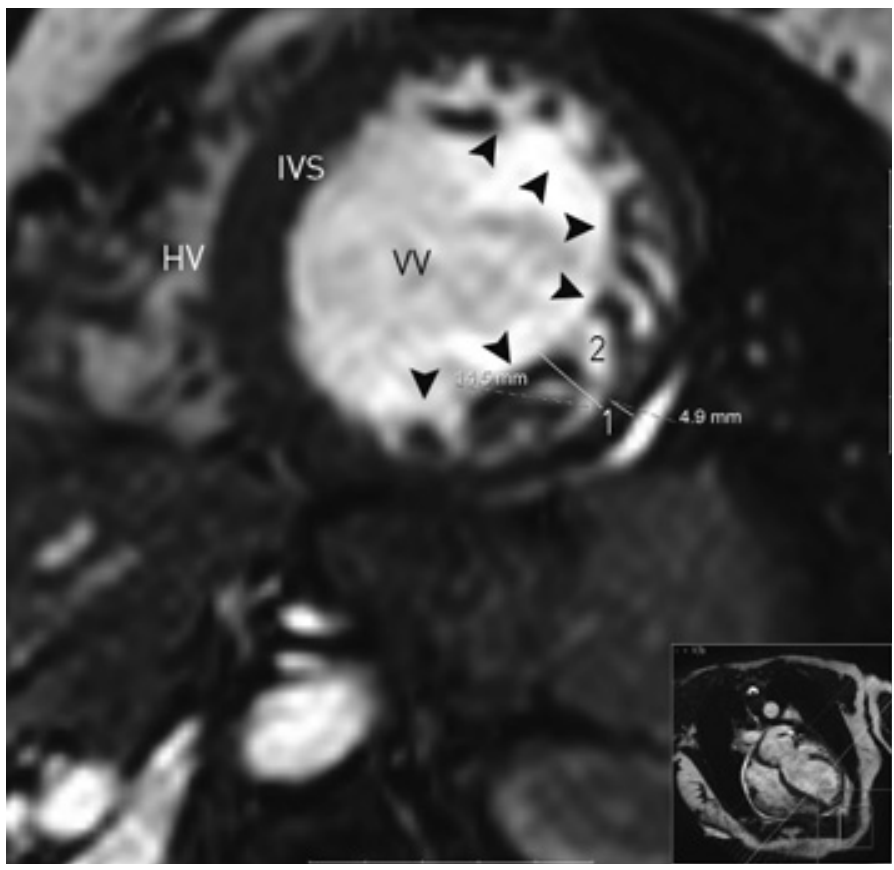

Figur 1 Transtorakal ekkokardiografi, parasternalt tverraksesnitt av venstre ventrikkel (VV). Inferolaterale vegg av venstre ventrikkel med uttalte trabekler (pilhoder) med dype recesser (piler) mellom trabeklene. Det normalt utviklede epikardiale myokardlaget (stjerne) i dette området er tydelig tynnere enn normalt jevnført med tykkelsen på interventrikulærseptum (IVS). $H V=$ høyre ventrikkel, $P M=$ posteromediale papillemuskel, $A L=$ anterolaterale papillemuskel, $P=$ perikard

Figur 2 Transtorakal ekkokardiografi, parasternalt tverraksesnitt av venstre ventrikkel (VV). Fargedopplerfremstilling av blodstrøm i venstre ventrikkel viser blodstrøm (stjerne) inn i de interventrikulære recessene. $H V=$ høyre ventrikkel, $P M=$ posteromediale papillemuskel, $A L=$ anterolaterale papillemuskel

Figur 3 Magnetisk resonanstomografi av hjertet. Endediastolisk tverraksesnitt av venstre (VV) og høyre (HV) ventrikkel. Laterale vegg med tilgrensende deler av nedre og fremre vegg (pilhoder) med manglende modningforandringer, med et tynnere epikardialt lag (måling 1: 4,9 mm) og et tykkere trabekulært endret endokardialt lag (måling 2: $14,5 \mathrm{~mm}$ ). Forholdet mellom endediastolisk tykkelse på indre og ytre lag er 3,0 
tramyokardiale hematomer/abscesser, aneurismer og metastaser til hjertet $(1,6-8,13)$.

\section{Genetikk og prevalens}

Både familiære og sporadiske tilfeller av manglende modning av venstre ventrikkel er beskrevet $(2,7,8,20,21)$. Den patomorfogenetiske mekanismen til denne medfødte hjertelidelsen er ikke funnet og er trolig heterogen. Det er funnet en rekke mutasjoner både i sporadiske og familiære tilfeller, så som kromosommutasjoner i Xq28 (G4.5gen), 17p11.2-12, 18q12, 11p15 og $5 q$ $(C S X$-gen $)(13,19)$. Flere av genene er hyppig affisert ved andre tilstander, både kardiale og ekstrakardiale $(13,22,23)$. For eksempel er mutasjon i 64.5 -genet også knyttet til Barths syndrom, X-kromosomalt arvet endokardial fibroelastose og X-kromosomalt arvet infantil kardiomyopati (19), og mutasjoner i MYH7-genet er assosiert med både manglende modning av venstre ventrikkel og hypertrofiske, restriktive og dilaterte kardiomyopatier (22). Både X-kromosomalt resessiv $(8,20)$ og autosomalt dominant $(8,24)$ arvegang er beskrevet. Tilstanden er funnet hyppigere hos mannlige enn kvinnelige pasienter $(6,8,9)$. Ved symptomdebut i barnealder synes tilstanden oftest å være X-kromosomalt arvet, mens ved symptomdebut $\mathrm{i}$ voksen alder er den oftest autosomalt dominant arvet (24). Fenotypen kan variere mye, selv ved samme genetiske årsak innen familien (25). Det anføres at facial dysmorfisme og andre dysmorfismetyper er vanligere ved symptomdebut i barnealder $(2,3)$. Genanalyser er nå mulig å utføre ved Seksjon for molekylærgenetikk, Medisinsk genetisk laboratorium, Rikshospitalet, Oslo. Vi kan ikke se at rutinemessig genetisk utredning er anbefalt $i$ litteraturen.

Tidligere ble manglende modning av venstre ventrikkel beskrevet som meget sjeldent, men tilstanden påvises nå hyppigere, med en forekomst på $0,05-0,24 \%$ i forskjellige ekkokardiografiske materialer (4). Den økte hyppigheten kan skyldes bedrede diagnostiske muligheter (ekkokardiografi, MR av hjertet) og økt bevissthet om lidelsen, men også genetiske forskjeller mellom de undersøkte gruppene kan spille en rolle (7). Diagnosen er blitt stilt $i$ alle aldre, fra prenatalt og opptil 92 år $(6,7,26)$. Manglende modning av venstre ventrikkel ble påvist hos $9 \%$ av australske barn med primær kardiomyopati og var den tredje hyppigste årsaken etter dilatert og hypertrofisk kardiomyopati (27). I en studie blant voksne hjertesviktpasienter fant man tilstanden hos $24 \%$ (28). Den høye prevalensen i denne undersøkelsen kan muligens skyldes at de diagnostiske kriteriene for tilstanden foreløpig er lite spesifikke, spesielt for pasienter av genetisk afrikansk opprinnelse.

\section{Kliniske manifestasjoner og behandling}

Både de kliniske manifestasjonene og alder ved diagnosetidspunkt varierer $(2,5,6,8$,
16, 29). Selv om manglende modning av venstre ventrikkel er en medfødt hjertelidelse, debuterer gjerne hjertesymptomene først i voksen alder, og det er beskrevet flere pasienter med symptomdebut etter fylte 60 år $(3,7)$. Dette kan skyldes varierende grad av manglende modning samt utvikling av tilleggssykdom som for eksempel iskemisk koronarsykdom $(1,30)$.

Pasientene kan utvikle progredierende hjertesvikt på grunn av systolisk og diastolisk dysfunksjon av venstre ventrikkel, med eller uten dysfunksjon av høyre ventrikkel i tillegg (1). Manglende modning av venstre ventrikkel med svekket ventrikkelfunksjon diagnostisert i tidlig barnealder, vil ofte vise forbigående bedring med senere forverring (15). Diastolisk dysfunksjon skyldes både unormal relaksasjon og redusert tøyningsevne i ventrikkelen. Den systoliske dysfunksjonen skyldes redusert myokardkontraksjon $\mathrm{i}$ affiserte deler av ventrikkelen, men dårlig samsvar mellom oksygenbehov og blodforsyning til områdene med trabekelforandringer kan også være av betydning, og pasienter med manglende modning av venstre ventrikkel har typisk mikrovaskulær dysfunksjon $(1,13,31)$. Hjertesvikten behandles etter vanlige retningslinjer, inklusive hjertetransplantasjon om nødvendig $(7,8$, $16,19,21,29,30)$.

I flere studier er det vist økt risiko for alvorlige ventrikulære takyarytmier og/eller plutselig død hos pasienter med denne tilstanden $(2,3,9,20,21,30)$, mens det $i$ andre studier ikke er vist nevneverdig økt risiko, selv etter lengre observasjonstid $(8,26)$. En del av forklaringen til denne diskrepansen kan være at de først omtalte studiene har inkludert sykere pasienter enn de andre (8). Det anbefales lav terskel for implantasjon av defibrillator hos pasienter etter en episode med potensielt alvorlig takyarytmi (10).

Pasientene er disponert for tromboemboliske hendelser, pga. trombedanninger i de dype intertrabekulære recessene, og supraventrikulære takyarytmier $(2,3,8,9)$. En relativt liberal praksis med profylaktisk antikoagulasjonsbehandling er derfor anbefalt $(1,9,16)$.

Forskjellige nevromuskulære lidelser (som myopatier) ses hyppig hos pasienter med manglende modning av venstre ventrikkel (6, 20). Slike lidelser ble påvist hos 40 av 49 pasienter i en studie (6). Det anbefales derfor at pasienter med manglende modning av venstre ventrikkel blir nevrologisk vurdert (6).

\section{Prognose}

Prognosen er gjerne angitt som dårlig, med $\varnothing k t$ morbiditet og mortalitet på grunn av progredierende hjertesvikt, systemiske embolier og maligne ventrikulære arytmier. I en familie med $X q 28$-relatert manglende modning av venstre ventrikkel døde fire barn i spedbarnsalderen, og i tillegg utviklet et barn hjertesvikt åtte måneder gammel og et barn ble hjertetransplantert ni måneder gam- mel (20). En annen studie på åtte pasienter i alderen 11 måneder-22 år viste tre dødsfall etter en oppfølgingstid på fem år (2). I et materiale på 34 pasienter, gjennomsnittlig 42 år ved diagnosetidspunktet, var 12 pasienter døde etter en gjennomsnittlig observasjonsperiode på 44 måneder. I samme periode hadde 18 pasienter utviklet betydelig hjertesvikt, åtte hadde hatt tromboemboliske hendelser, 14 hadde hatt ventrikulære takykardiepisoder og fire var hjertetransplanterte (9). I et annet materiale på 17 pasienter (alder 18-71 år) var åtte pasienter døde og to hjertetransplanterte etter en oppfølgingsperiode på seks år (3). Pasienter som var asymptomatiske på diagnosetidspunktet, hadde den beste prognosen.

Imidlertid har det vært stilt spørsmål om prognosen jevnt over er så alvorlig som ovenfor angitt $(8,9,15,21,26,29)$. I et japansk materiale på 27 pasienter (alder 1 uke-15 år) som ble identifisert ut fra screening, var bare to døde etter en median oppfølgingsperiode på seks år, men 14 av de 27 pasientene hadde utviklet svekket hjertefunksjon i samme observasjonsperiode (8). I en annen studie på 45 pasienter (hvorav 30 med utvidet og svekket venstre ventrikkel og gjennomsnittlig NYHA-klasse 2,3 ved inklusjonstidspunktet) med gjennomsnittsalder på 37 år på diagnosetidspunktet, døde bare én pasient under en gjennomsnittlig oppfølgingsperiode på 46 måneder (21). Hos de pasientene som hadde normal systolisk venstre ventrikkel-funksjon ved inklusjonstidspunktet, forekom det verken død eller utvikling av hjertesvikt i observasjonsperioden. I en observasjonsstudie på 238 pasienter (alder 1-92 år) hadde bare 11 pasienter kliniske tegn på eller 24 timers EKGfunn på ventrikkeltakykardi under en gjennomsnittlig oppfølgingsperiode på vel fire år, og bare to av disse pasientene utviklet potensielt livstruende arytmi i denne perioden (26). Funn av manglende modning av venstre ventrikkel hos en asymptomatisk pasient, enten dette funnet er tilfeldig eller som ledd i familiescreening, er assosiert med høy sannsynlighet for stabil situasjon og god prognose gjennom flere år (29). Dilatasjon av venstre ventrikkel, symptomer på hjertesvikt, kronisk atrieflimmer, grenblokk og tidligere episode med potensielt livstruende ventrikkeltakykardi er derimot anført som klart negative prediktorer for overlevelse hos disse pasientene $(9,29)$.

En systematisk familiescreening viste at seks og to av 32 asymptomatiske slektninger hadde henholdsvis manglende modning av venstre ventrikkel og andre ekkokardiografiske venstre ventrikkel-anomalier (21). I andre studier er det også funnet økt hyppighet av andre hjerteanomalier i familien til disse pasientene $(22,23)$. På grunn av usikker til dårlig prognose hos pasienter med manglende modning av venstre ventrikkel er det anbefalt ekkokardiografisk screening av førstegradsslektninger $(9,19)$. 


\section{Konklusjon}

Manglende modning av venstre ventrikkels myokard er nylig beskrevet som en årsak til kardiomyopati. Tilstanden kan lettest påvises ved ekkokardiografi eller MR-undersøkelse av hjertet. Det er viktig å ikke overse denne tilstanden, siden den disponerer for alvorlige følger i form av hjertesvikt, tromboemboliske hendelser, ventrikulære takyarytmier og død. Det er grunn til å tro at manglende modning av venstre ventrikkel er mindre sjeldent enn tidligere antatt. Tidlig diagnose vil kunne gi disse pasientene bedre oppfølging og behandling.

\section{Oppgitte interessekonflikter: Ingen}

\section{Litteratur}

1. Agmon Y, Connolly HM, Olson LJ et al. Noncompaction of the ventricular myocardium. J Am Soc Echocardiogr 1999; $12: 859-63$.

2. Chin TK, Perloff JK, Williams RG. Isolated noncompaction of left ventricular myocardium. A study of eight cases. Circulation 1990; 82: 507-13.

3. Ritter M, Oechslin E, Sütsch $G$ et al. Isolated noncompaction of the myocardium in adults. Mayo Clin Proc 1997: 72: 26-31.

4. Freedom RM, Yoo S-J, Perrin D et al. The morphological spectrum of ventricular noncompaction. Cardiol Young 2005; 15: 345-64.

5. Jenni R, Oechslin E, Schneider J et al. Echocardiographic and pathoanatomical characteristics of isolated left ventricular non-compaction: a step towards classification as a distinct cardiomyopathy. Heart 2001; 86: 666-71.

6. Stöllberger C. Finsterer J, Blazek K. Left ventricular hypertrabeculation/ noncompaction and association with additional cardiac abnormalities and neuromuscular disorders. Am J Cardiol 2002; 90: 899-902.

7. Stöllberger C, Finsterer J. Left ventricular hypertrabeculation/noncompaction. J Am Soc Echocardiogr 2004; 17: $91-100$

8. Ichida F, Hamamichi Y, Miyawaki T et al. Clinical features of isolated noncompaction of the ventricular myocardium. J Am Coll Cardiol 1999; 34 : 233-40.

9. Oechslin EN, Jost CHA, Rojas JR et al. Long-term follow-up of 34 adults with isolated left ventricular noncompaction: a distinct cardiomyopathy with poor progonosis. J Am Coll Cardiol 2000; 36: 493-500.

10. Oechslin E, Jenni R. Isolated left ventricular noncompaction: Increasing recognition of this distinct, yet «unclassified» cardiomyopathy. Eur J Echocardiogr 2002; 3: 250-1.

11. Frischknecht BS, Jost CHA, Oechslin EN et al. Validation of noncompaction criteria in dilated cardiomyopathy, and valvular and hypertensive heart disease. J Am Soc Echocardiogr 2005; 18: 865-72.

12. Petersen SE, Selvanayagam JB, Wiesmann F et al. Left ventricular non-compaction. Insights from cardiovascular magnetic resonance imaging. J Am Coll Cardiol 2005; 46: $101-5$

13. Bartram U, Bauer J, Schranz D. Primary noncompaction of the ventricular myocardium from the morfogenetic standpoint. Pediatr Cardiol 2007; 28: 325-32.

14. Bellet S, Gouley BA. Congenital heart disease with multiple cardiac anomalies: report of case showing aortic atresia, fibrous scar in myocardium and embryonal sinusoidal remains. Am J Med Sci 1932: 183: 458-65.

15. Pignatelli RH, McMahon CJ, Dreyer WJ et al. Clinical characterization of left ventricular noncompaction in children: a relatively common form of cardiomyopathy. Circulation 2003; 108: 2672-8.

16. Weiford BC, Subbarao VD, Mulhern KM. Noncompaction of the ventricular myocardium. Circulation 2004; 109: 2965-71.

17. Maron BJ, Towbin JA, Thiene $G$ et al. Contemporary definitions and classification of the cardiomyopathies. An American Heart Association scientific statement from the Council on Clinical Cardiology, Heart Failure and Transplantation Committee
Quality of Care and Outcomes Research and Functional Genomics and Translational Biology Interdisciplinary Working Groups; and Council on Epidemiology and Prevention. Circulation 2006; 113 . 1807-16.

18. de Groot-de Laat LE, Krenning BJ, ten Cate FJ et al. Usefulness of contrast echocardiography for diagnosis of left ventricular noncompaction. Am J Cardiol 2005: 95: 1130-4.

19. Jenni R, Oechslin EN, van der Loo B. Isolated ventricular non-compaction of the myocardium in adults. Heart 2007; 93: 11-5.

20. Bleyl SB, Mumford BR, Brown-Harrison M-C et al. Xq28-linked noncompaction of the left ventricular myocardium: prenatal diagnosis and pathologic analysis of affected individuals. Am J Med Genet 1997; 72: 257-65.

21. Murphy RT. Thaman R, Blanes JG et al. Natural history and familial characteristics of isolated left ventricular non-compaction. Eur Heart J 2005; 26: 187-92.

22. Hoedemaekers YM, Caliskan K, Majoor-Krakauer $D$ et al. Cardiac $\beta$-myosin heavy chain defects in two families with non-compaction cardiomyopathy: linking non-compaction to hypertrophic, restrictive, and dilated cardiomyopathies. Eur Heart J 2007; 28: 2732-7.

23. Monserrat L, Hermida-Prieto M. Fernandez X et al. Mutation in the alpha-cardiac actin gene associated with apical hypertrophic cardiomyopathy, left ventricular non-compaction, and septal defects. Eur Heart J 2007; 28: $1953-61$.

24. Sasse-Klaassen S, Gerull B, Oechslin E et al. Isolated noncompaction of the left ventricular myocardium in the adult is an autosomal dominant disorder in the majority of patients. Am J Med Genet 2003; 119A: 162-7.

25. Johnson MT, Zhang S, Gilkeson R et al. Intrafamilial variability of noncompaction of the ventricular myocardium. Am Heart J 2006; 151: 1012.e7-14.

26. Fazio G, Corrado G, Zachara E et al. Ventricular tachycardia in non-compaction of left ventricle: Is this a frequent complication? Pacing Clin Electrophysiol 2007; 30: 544-6.

27. Nugent AW, Daubeney PEF, Chondros P et al. The epidemiology of childhood cardiomyopathy in Australia. N Engl J Med 2003; 348: 1639-46.

28. Kohli SK, Pantazis AA, Shah JS et al. Diagnosis of left-ventricular non-compaction in patients with left-ventricular systolic dysfunction: time for a reappraisal of diagnostic criteria? Eur Heart J 2008; 29: 89-95.

29. Lofiego C, Biagini E, Pasquale F. Wide spectrum of presentation and variable outcomes of isolated left ventricular non-compaction. Heart 2007; 93 $65-71$.

30. Wald R, Veltman G, Golding F et al. Determinants of outcome in isolated ventricular noncompaction in childhood. Am J Cardiol 2004; 94: 1581-4.

31. Jenni R, Wyss CA Oechslin EN Isolated ventricular noncompaction is associated with coronary microcirculatory dysfunction. J Am Coll Cardiol 2002; 39 $450-4$.

Manuskriptet ble mottatt 28.5. 2008 og godkjent 19.3. 2009. Medisinsk redaktør Siri Lunde. 